\title{
Overweight and obesity and the health of populations of PALOP
}

\author{
Excesso de peso e obesidade e a saúde das populações dos PALOP
}

\author{
Vitor Rosado-Marques \\ Faculdade de Motricidade Humana, Universidade de Lisboa, \\ Estrada da Costa, 1499-002 Lisboa, Portugal \\ Centro de Investigação em Antropologia e Saúde, Universidade de Coimbra, Coimbra, Portugal \\ E-mail: vrosadomarques@gmail.com
}

Este artigo foi apresentado como comunicação oral no seminário "Segurança Alimentar e Nutricional na Medicina Tropical caminhos comuns na CPLP", realizado como encontro satélite do $3^{\circ}$ Congresso Nacional de Medicina Tropical, no dia 17 de Abril de 2015

\begin{abstract}
The prevalence of overweight and obesity continues to increase globally, particularly obesity. This increase is more pronounced in countries with lower income, putting the health systems of these countries, already quite weak, at risk. The data available for the Portuguese-speaking African countries (PALOP), in addition to being scarce, show an enormous diversity, which may be related to different methodologies of collection. Even so, it allows the observation that the situation is, in general, quite worrying and that for women the values are very high. Knowing the strong association between overweight/obesity and non-communicable diseases (NCDs), there should be a special attention of the health authorities to this problem. NCDs are becoming increasingly frequent in Africa and in sub-Saharan Africa, where communicable diseases and undernutrition still predominate, already accounting for $25 \%$ of deaths. The incidence and prevalence of overweight/obesity and NCDs in the PALOP are not yet fully identified, so an investment in research that will allow the implementation of actions to prevent and control excess weight, particularly in childhood, is necessary along with other actions aimed at combating existing nutritional problems in these countries.
\end{abstract}

Keywords: overweight; obesity; NCDs; PALOP; Africa

\section{Resumo}

A prevalência do excesso de peso e da obesidade continua a aumentar a nível global, em particular a obesidade. Este aumento é mais acentuado nos países de menores rendimentos o que coloca em risco os sistemas de saúde destes países, já de si bastante débeis. Os dados disponíveis para os países de língua oficial portuguesa (PALOP), para além de serem escassos, apresentam uma enorme diversidade, o que poderá estar relacionado com diferentes metodologias de recolha. No entanto, permitem ver que a situação, em geral, é preocupante e que no caso das mulheres os valores são muito elevados. Conhecendo-se a forte associação que existe entre o excesso de peso/ obesidade com as doenças não transmissíveis (DNT), deve haver uma especial atenção das autoridades de saúde para este problema. As DNT estão a tornar-se cada vez mais frequentes em África e na África subsaariana, onde ainda predominam as doenças transmissíveis e a desnutrição, sendo já responsáveis por $25 \%$ das mortes. A incidência e a prevalência do excesso de peso/obesidade e das DNT nos PALOP ainda não estão completamente identificadas, pelo que é necessário um investimento na investigação que venha a permitir a implementação de ações para prevenir e controlar o excesso de peso, em particular na infância, em simultâneo com outras ações dirigidas ao combate dos problemas nutricionais existentes nestes países.

Palavras-chave: Excesso de Peso; Obesidade; DNT; PALOP; África. 


\section{Introduction}

Although some studies suggest stability in the values of overweight and obesity in some countries ${ }^{1,2,3}$, the global prevalence of these conditions have increased $27.5 \%$ in adults and $47.1 \%$ in children between 2008 and $2013^{4}$. The last Global Nutrition Report ${ }^{5}$, based on data from the World Health Organization (WHO), concludes that in all countries for which the WHO has data there was an increase in the prevalence of obesity between 2010 and $2014^{6}$.

This increase was not only in industrialized countries but also in developing countries, although differently between men and women ${ }^{4}$.

Urban populations and women in West Africa are at high risk of overweight/obesity (overweight and obesity combined), with a faster increase in obesity in women ${ }^{7}$. Overweight and obesity can have a serious impact on the health of individuals and are associated with cardiovascular diseases (mainly heart disease and stroke), type 2 diabetes, musculoskeletal disorders like osteoarthritis, and certain types of cancer. Thus, overweight/ obesity is responsible for premature death and for a high disability ${ }^{8}$.

The recent growth of non-communicable diseases (NCDs) in developing countries, coexisting with infectious diseases and child malnutrition, is a risk to health and poses a huge threat to the health systems of these countries. This is referred to as the double burden of disease $e^{9}$.

In Africa, NCDs are becoming the main cause of death. In Sub-Saharan Africa, where infectious diseases and malnutrition are still prevalent, NCDs are currently responsible for over $25 \%$ of deaths and the estimates suggest that by 2030 they will be the main cause of death ${ }^{10}$. In this continent, the risk of non-communicable diseases related to nutrition varies between different regions and countries. The simultaneous presence of high rates of low birth weight, chronic malnutrition and greater availability of energy-dense foods may lead in future to a significant increase in NCDs related to nutrition ${ }^{11}$.

\section{Overweight and obesity}

The World Health Organization defines overweight and obesity as an abnormal or excessive fat accumulation that may impair health ${ }^{12}$.

\section{Introdução}

Apesar de alguns estudos apontarem para uma estabilidade nos valores do excesso de peso e obesidade nalguns países ${ }^{1,2,3}$, a sua prevalência, a nível mundial, aumentou $27,5 \%$ nos adultos e $47,1 \%$ nas crianças, entre 2008 e $2013^{4}$.

O último relatório mundial de nutrição ${ }^{5}$, com base nos dados da Organização Mundial de Saúde (OMS) ${ }^{6}$, conclui que em todos países sobre os quais a OMS dispõe de dados houve um aumento da prevalência de obesidade entre 2010 e 2014.

Este aumento verificou-se não apenas nos países industrializados, mas também nos países em desenvolvimento, embora de modo diferente entre homens e mulheres ${ }^{4}$ As populações urbanas e as mulheres da África Ocidental apresentam um elevado risco de excesso de peso/ obesidade (excesso de peso e obesidade combinados) verificando-se um aumento mais rápido da obesidade nas mulheres ${ }^{7}$.

$\mathrm{O}$ excesso de peso e a obesidade podem ter um sério impacto sobre a saúde dos indivíduos, estando associados a doenças cardiovasculares (principalmente doenças cardíacas e acidente vascular cerebral), diabetes tipo 2, doenças músculo-esqueléticas, como osteoartrite, e a alguns tipos de cancro. Deste modo, o excesso de peso/obesidade é responsável pela morte prematura e por uma elevada incapacidade . $^{8}$.

O recente crescimento das doenças não transmissíveis (DNT) nos países em desenvolvimento, coexistindo com as doenças infecciosas e com a desnutrição infantil, são um risco para a saúde e representam uma enorme ameaça para os sistemas de saúde destes países, constituindo aquilo a que se chama dupla carga da doença ${ }^{9}$. Em África, as DNT estão a tornar-se principal causa de morte. Na África Subsaariana, onde as doenças transmissíveis e a desnutrição são ainda predominantes, as DNT são atualmente responsáveis por mais de $25 \%$ das mortes e as estimativas apontam para que em 2030 sejam a principal causa de morte $^{10}$.

Neste continente o risco de DNT relacionadas com a nutrição varia entre as diversas regiões e países. A presença simultânea de elevadas taxas de baixo peso ao nascimento, de desnutrição crónica e uma maior disponibilidade de alimentos altamente energéticos poderá levar no futuro a um aumento significativo de DNT relacionadas com a nutrição ${ }^{11}$.

\section{Excesso de Peso e Obesidade}

A Organização Mundial de Saúde define o excesso de peso e a obesidade como uma acumulação anormal ou excessiva de gordura capaz de prejudicar a saúde ${ }^{12}$. 
Body mass index (BMI), defined as a person's weight in kilograms divided by the square of the person's height in metres $\left(\mathrm{kg} / \mathrm{m}^{2}\right)$, is commonly used to classify an adult as being overweight (BMI $\geq 25)$ or obese (BMI $\geq 30)^{12}$.

Since 1980, obesity values have more than doubled, in 2014 there were more than 600 million obese adults $(13 \%)$ and almost 2 billion were considered overweight (39\%). This increase is also visible in children, reaching 42 million children under five years of age considered overweight or obese in $2013^{12}$.

The journal The Lancet published a study with data from 188 countries in which the authors report that about a third of the world's population is overweight or obese and $62 \%$ of these people live in developing countries. The author also pointed to the fact that if the rising trends continue at current levels $18 \%$ of men and $21 \%$ of women will be obese by $2025^{4}$.

Once considered as a problem of rich countries, currently overweight and obesity have had a greater increase in less developed countries, particularly in urban settings ${ }^{12}$.

Although it is a global problem, overweight/obesity have different patterns depending on the development level of the country. In industrialized countries the highest prevalence of these conditions is among men, while in developing countries it is women who have the highest values ${ }^{4}$.

The number of recorded cases of overweight/obesity has increased in the last 30 years and although some industrialized countries have shown a slowdown since 2006, in developing countries there has been a marked increase ${ }^{4}$.

Also emerging from the this study ${ }^{4}$, coordinated by Marie $\mathrm{Ng}$, is that the prevalence of overweight/obesity is also increasing in children and adolescents in developing countries, and increased in boys from about $8 \%$ in 1980 to nearly $13 \%$ in 2013 , and in girls of about $8.5 \%$ to about $13.5 \%$.

Guinea-Bissau has the highest obesity rate, in the Portuguese-Speaking African Countries (PALOP), 24.2\% in women and $16.8 \%$ in men and about $8 \%$ in young people of both sexes. Angola is the country with the second highest values of $18.7 \%$ and $12.0 \%$ in women and men, respectively. The following are, respectively in women and men, Sao Tome and Principe (17.6\% and $7.1 \%$ ), Cape Verde (15.4\% and 7.0\%) and Mozambique with the lowest levels (9.2\% and 3.5\%,) (Table 1). In all cases, the prevalence rates have been increasing since $1980^{4}$.

Data on the prevalence of overweight/obesity available for the PALOP are limited, and is particularly scarce for children under five years of age. Furthermore, there
O índice de massa corporal (IMC), definido pela razão entre o peso $(\mathrm{kg})$ e o quadrado da estatura (m2), é normalmente utilizado para classificar um adulto como tendo excesso de peso (IMC $\geq 25$ ) ou obeso $(\mathrm{IMC} \geq 30)^{12}$. Desde 1980 que os valores da obesidade mais do que duplicaram, havendo em 2014 mais de 600 milhões de adultos obesos (13\%) e quase 2 biliões com excesso de peso $(39 \%)$. Também nas crianças esse aumento é visível, existindo, em 2013, 42 milhões de crianças com menos de 5 anos com excesso de peso ou obesas ${ }^{12}$.

O jornal The Lancet publicou um estudo realizado com dados de 188 países onde os autores referem que cerca de um terço da população mundial tem excesso de peso ou é obesa e que $62 \%$ destas pessoas vivem em países em desenvolvimento. Alertam ainda para o facto de que, se as tendências de subida se mantiverem nos níveis atuais, em 2025, 18\% dos homens e $21 \%$ das mulheres serão obesos ${ }^{4}$.

Outrora considerado como um problema dos países ricos, atualmente o excesso de peso e a obesidade apresentam um maior aumento nos países menos desenvolvidos, particularmente nos centros urbanos ${ }^{12}$.

Embora seja um problema global, o excesso de peso/ obesidade tem padrões diferentes consoante o nível de desenvolvimento dos países. Nos países industrializados as maiores prevalências de excesso de peso/obesidade encontram-se entre os homens, enquanto nos países em desenvolvimento são as mulheres que apresentam os valores mais elevados ${ }^{4}$.

O número de casos de excesso de peso/obesidade tem aumentado nos últimos 30 anos e, embora alguns países industrializados apresentem um abrandamento desde 2006, nos países em desenvolvimento esse aumento tem-se acentuado ${ }^{4}$.

Neste estudo ${ }^{4}$, coordenado por Marie $\mathrm{Ng}$, conclui-se ainda que a prevalência de excesso de peso/obesidade está também a subir nas crianças e adolescentes nos países em desenvolvimento, tendo aumentado nos rapazes de cerca de $8 \%$ em 1980, para cerca de $13 \%$ em 2013, e nas raparigas de cerca de $8,5 \%$ para cerca de $13,5 \%$. A Guiné-Bissau é o país africano de língua oficial portuguesa (PALOP) que apresenta a maior taxa de obesidade, $24,2 \%$ nas mulheres e $16,8 \%$ nos homens e cerca de $8 \%$ nos jovens de ambos os sexos. Angola é o segundo país com valores mais elevados, de $18,7 \%$ e $12,0 \%$ nas mulheres e homens, respetivamente. Seguem-se respectivamente, nas mulheres e nos homens São Tomé e Príncipe (17,6\% e 7,1\%), Cabo Verde (15,4\% e 7,0\%) e Mozambique com os valores baixos $(9,2 \%$ e $3,5 \%)$ (tabela 1). Em todos os casos, desde 1980, que as prevalências têm vindo a aumentar ${ }^{4}$.

Os dados da prevalência de excesso de peso/obesidade disponíveis para os PALOP são pouco abundantes, sendo particularmente escassos os referentes a crianças 
is a huge variability among the information available, likely due to different methodologies in collecting data, in estimates or classification of individuals.

Table 1 presents a summary of the data, adjusted for age and sex, reported in the study of Marie $\mathrm{Ng}$ and colleagues ${ }^{4}$. com menos de 5 anos. Para além disso, observa-se uma enorme variabilidade entre a informação disponível, provavelmente devido a diferentes metodologias na recolha dos dados, nas estimativas ou na classificação dos indivíduos.

Na tabela 1 apresenta-se uma síntese dos dados, ajustados para a idade e sexo, constantes no estudo de Marie $\mathrm{Ng}$ e colaboradores ${ }^{4}$.

Table 1. Age-standardised estimates of the prevalence of overweight and obesity combined $(\mathrm{OvW}+\mathrm{Ob})$ and obesity alone $(\mathrm{Ob})$ for girls, boys, men, and women of the PALOP for 2013

(\%) $(\mathrm{Ng}$ et al., 2014)

\begin{tabular}{|c|c|c|c|c|c|c|c|c|}
\hline & \multicolumn{2}{|c|}{ Boys $(<20$ years $)$} & \multicolumn{2}{|c|}{ Men ( $\geq 20$ years) } & \multicolumn{2}{|c|}{ Girls $(<20$ years $)$} & \multicolumn{2}{|c|}{ Women ( $\geq 20$ years) } \\
\hline & $\mathrm{OvW}+\mathrm{Ob}$ & $\mathrm{Ob}$ & $\mathrm{OvW}+\mathrm{Ob}$ & $\mathrm{Ob}$ & $\mathrm{OvW}+\mathrm{Ob}$ & $\mathrm{Ob}$ & $\mathrm{OvW}+\mathrm{Ob}$ & $\mathrm{Ob}$ \\
\hline Angola & $\begin{array}{c}15.5 \\
(13.0-18.3)\end{array}$ & $\begin{array}{c}5.7 \\
(4.6-7.0)\end{array}$ & $\begin{array}{c}42.9 \\
(40.1-45.7)\end{array}$ & $\begin{array}{c}12.0 \\
(10.7-13.4)\end{array}$ & $\begin{array}{c}20.9 \\
(17.5-24.6)\end{array}$ & $\begin{array}{c}6.0 \\
(4.7-7.5)\end{array}$ & $\begin{array}{c}49.1 \\
(46.1-52.0)\end{array}$ & $\begin{array}{l}18.7 \\
(16.7- \\
20.9)\end{array}$ \\
\hline Cabo Verde & $\begin{array}{c}11.5 \\
(9.6-13.7) \\
\end{array}$ & $\begin{array}{c}3.3 \\
(2.6-4.0) \\
\end{array}$ & $\begin{array}{c}31.8 \\
(29.4-34.3) \\
\end{array}$ & $\begin{array}{c}7.0 \\
(6.2-7.8) \\
\end{array}$ & $\begin{array}{c}18.3 \\
(15.0-21.7) \\
\end{array}$ & $\begin{array}{c}5.2 \\
(4.1-6.5) \\
\end{array}$ & $\begin{array}{c}44.0 \\
(41.3-47.0) \\
\end{array}$ & $\begin{array}{l}15.4 \\
(13.9- \\
17.1) \\
\end{array}$ \\
\hline $\begin{array}{l}\text { Guinea- } \\
\text { Bissau }\end{array}$ & $\begin{array}{c}15.8 \\
(13.3-18.5)\end{array}$ & $\begin{array}{c}8.1 \\
(6.6-9.8)\end{array}$ & $\begin{array}{c}44.0 \\
(41.1-46.9)\end{array}$ & $\begin{array}{c}16.8 \\
(15.1-18.6)\end{array}$ & $\begin{array}{c}20.4 \\
(17.2-23.8)\end{array}$ & $\begin{array}{c}8.3 \\
(6.7-10.3)\end{array}$ & $\begin{array}{c}47.8 \\
(44.8-50.8)\end{array}$ & $\begin{array}{l}24.2 \\
(21.8- \\
26.7)\end{array}$ \\
\hline Mozambique & $\begin{array}{c}12.3 \\
(10.4-14.4) \\
\end{array}$ & $\begin{array}{c}3.5 \\
(2.9-4.3) \\
\end{array}$ & $\begin{array}{c}14.1 \\
(12.7-15.6) \\
\end{array}$ & $\begin{array}{c}3.5 \\
(3.0-3.9) \\
\end{array}$ & $\begin{array}{c}14.4 \\
(12.3-16.9) \\
\end{array}$ & $\begin{array}{c}3.0 \\
(2.4-3.7) \\
\end{array}$ & $\begin{array}{c}26.5 \\
(24.6-28.3) \\
\end{array}$ & $\begin{array}{c}9.2 \\
(8.3-10.3) \\
\end{array}$ \\
\hline $\begin{array}{l}\text { Sao Tome } \\
\text { and Principe }\end{array}$ & $\begin{array}{c}12.3 \\
(10.3-14.4)\end{array}$ & $\begin{array}{c}4.4 \\
(3.6-5.5) \\
\end{array}$ & $\begin{array}{c}30.6 \\
(28.4-33.0)\end{array}$ & $\begin{array}{c}7.1 \\
(6.4-7.9) \\
\end{array}$ & $\begin{array}{c}18.9 \\
(16.0-22.0)\end{array}$ & $\begin{array}{c}5.8 \\
(4.5-7.3) \\
\end{array}$ & $\begin{array}{c}45.7 \\
(43.1-48.3) \\
\end{array}$ & $\begin{array}{l}17.6 \\
(16.0- \\
19.2) \\
\end{array}$ \\
\hline
\end{tabular}

Tabela 1. Estimativa das prevalências de excesso de peso + obesidade $(\mathrm{ExP}+\mathrm{Ob})$ e da obesidade $(\mathrm{Ob})$ ajustadas para a idade, em rapazes, raparigas, homens e mulheres dos

PALOP $(\%)(\mathrm{Ng} \text { et al., 2014) })^{4}$

\begin{tabular}{|c|c|c|c|c|c|c|c|c|}
\hline & \multicolumn{2}{|c|}{ Boys ( $<20$ years) } & \multicolumn{2}{|c|}{ Men ( $\geq 20$ years) } & \multicolumn{2}{|c|}{ Girls (<20 years) } & \multicolumn{2}{|c|}{ Women ( $\geq 20$ years) } \\
\hline & $\mathrm{OvW}+\mathrm{Ob}$ & $\mathrm{Ob}$ & $\mathrm{OvW}+\mathrm{Ob}$ & $\mathrm{Ob}$ & $\mathrm{OvW}+\mathrm{Ob}$ & $\mathrm{Ob}$ & $\mathrm{OvW}+\mathrm{Ob}$ & $\mathrm{Ob}$ \\
\hline Angola & $\begin{array}{c}15.5 \\
(13.0-18.3)\end{array}$ & $\begin{array}{c}5.7 \\
(4.6-7.0)\end{array}$ & $\begin{array}{c}42.9 \\
(40.1-45.7)\end{array}$ & $\begin{array}{c}12.0 \\
(10.7-13.4)\end{array}$ & $\begin{array}{c}20.9 \\
(17.5-24.6) \\
\end{array}$ & $\begin{array}{c}6.0 \\
(4.7-7.5)\end{array}$ & $\begin{array}{c}49.1 \\
(46.1-52.0)\end{array}$ & $\begin{array}{l}18.7 \\
(16.7- \\
20.9) \\
\end{array}$ \\
\hline Cabo Verde & $\begin{array}{c}11.5 \\
(9.6-13.7)\end{array}$ & $\begin{array}{c}3.3 \\
(2.6-4.0) \\
\end{array}$ & $\begin{array}{c}31.8 \\
(29.4-34.3)\end{array}$ & $\begin{array}{c}7.0 \\
(6.2-7.8) \\
\end{array}$ & $\begin{array}{c}18.3 \\
(15.0-21.7)\end{array}$ & $\begin{array}{c}5.2 \\
(4.1-6.5)\end{array}$ & $\begin{array}{c}44.0 \\
(41.3-47.0)\end{array}$ & $\begin{array}{l}15.4 \\
(13.9- \\
17.1) \\
\end{array}$ \\
\hline $\begin{array}{l}\text { Guinea- } \\
\text { Bissau }\end{array}$ & $\begin{array}{c}15.8 \\
(13.3-18.5)\end{array}$ & $\begin{array}{c}8.1 \\
(6.6-9.8) \\
\end{array}$ & $\begin{array}{c}44.0 \\
(41.1-46.9)\end{array}$ & $\begin{array}{c}16.8 \\
(15.1-18.6)\end{array}$ & $\begin{array}{c}20.4 \\
(17.2-23.8)\end{array}$ & $\begin{array}{c}8.3 \\
(6.7-10.3)\end{array}$ & $\begin{array}{c}47.8 \\
(44.8-50.8)\end{array}$ & $\begin{array}{l}24.2 \\
(21.8- \\
26.7)\end{array}$ \\
\hline Mozambique & $\begin{array}{c}12.3 \\
(10.4-14.4)\end{array}$ & $\begin{array}{c}3.5 \\
(2.9-4.3)\end{array}$ & $\begin{array}{c}14.1 \\
(12.7-15.6)\end{array}$ & $\begin{array}{c}3.5 \\
(3.0-3.9)\end{array}$ & $\begin{array}{c}14.4 \\
(12.3-16.9)\end{array}$ & $\begin{array}{c}3.0 \\
(2.4-3.7)\end{array}$ & $\begin{array}{c}26.5 \\
(24.6-28.3)\end{array}$ & $\begin{array}{c}9.2 \\
(8.3-10.3)\end{array}$ \\
\hline $\begin{array}{l}\text { Sao Tome } \\
\text { and Principe }\end{array}$ & $\begin{array}{c}12.3 \\
(10.3-14.4)\end{array}$ & $\begin{array}{c}4.4 \\
(3.6-5.5)\end{array}$ & $\begin{array}{c}30.6 \\
(28.4-33.0)\end{array}$ & $\begin{array}{c}7.1 \\
(6.4-7.9)\end{array}$ & $\begin{array}{c}18.9 \\
(16.0-22.0)\end{array}$ & $\begin{array}{c}5.8 \\
(4.5-7.3)\end{array}$ & $\begin{array}{c}45.7 \\
(43.1-48.3)\end{array}$ & $\begin{array}{c}17.6 \\
(16.0- \\
19.2)\end{array}$ \\
\hline
\end{tabular}

As mentioned above, Guinea-Bissau and Angola are the countries with the highest prevalence; in all of the countries, with the exception of Mozambique, women have a prevalence higher than $35 \%$, the figure above which these conditions are considered a serious public health problem ${ }^{5}$.

However, results published later in world reports ${ }^{5,13,14}$ present lower values, and some differed markedly, as is the case of Guinea-Bissau. According to these reports, the countries with a more worrying situation are Cape
Como referido atrás, a Guiné-Bissau e Angola são os países com as maiores prevalências; em todos eles, com exceção de Moçambique, as mulheres apresentam prevalências superiores a 35\%, valor acima do qual o excesso de peso/obesidade é considerado um problema grave de saúde pública ${ }^{5}$

No entanto, resultados publicados posteriormente em relatórios mundiais ${ }^{5,13,14}$ apresentam valores inferiores, sendo algumas diferenças bastante acentuadas, como é o caso da Guiné-Bissau. De acordo com estes relató- 
Verde and Sao Tome and Principe, where the prevalence of overweight/obesity in women exceeds the $35 \%$ mentioned above. For men the prevalence rates are between $24 \%$ and $32 \%$. In the case of children less than five years of age, only the World Bank study shows values and for 2008 a greater prevalence was observed in Sao Tome and Principe, $12.1 \%$ and $11.1 \%$, respectively for girls and boys.

These differences may be due, as already mentioned, to different methodologies, namely the lack of adjustment for confounding variables.

\section{The impact of overweight/obesity on the health of populations}

Overweight and obesity are responsible for an increased risk of illness and death, particularly because of their association with cardiovascular diseases (hypertension, coronary heart disease, heart disease and stroke), type 2 diabetes, and musculoskeletal diseases, as osteoarthritis, obstructive sleep apnea and certain types of cancer ${ }^{6,8}$.

Thus, while aware of the potential contribution of other factors, the prevalence of these conditions can be a good indicator of some non-communicable diseases, particularly cardiovascular disease and diabetes.

Non-communicable diseases (NCDs) are a major challenge for the health and development of countries, particularly those with fewer resources. They are the leading cause of death worldwide, accounting for 38 million (68\%) of the 56 million deaths worldwide in 2012. Over $40 \%$ of these deaths occurred in individuals under the age of 70 years. Nearly three-quarters of all deaths from NCDs and the majority of premature deaths occur in low and middle income countries ${ }^{6}$.

Recognizing the importance of the impact of NCDs in developing countries, WHO developed the Global Action Plan for NCDs, which aims to assist countries in the prevention and control of NCDs for the period 2013-2020. This plan, approved by the World Health Assembly in 2013, includes a set of nine targets and a global monitoring framework for $\mathrm{NCDs}^{6,15}$.

These nine targets reflect the priority that countries must give to certain actions in order to reduce the risk factors of NCDs, including the concern to halt the rise in diabetes and obesity (seventh target).

The marked global increase in obesity in the last thirty years, and particularly in countries with lower incomes, is a threat to the health and development of populations. Diabetes is a chronic disease that occurs when the pancreas does not produce enough insulin (type 1), or when the body cannot use the insulin that is produced (Type $2)^{13}$. It is a serious disease, responsible for premature rios, os países que apresentam uma situação mais preocupante são Cabo Verde e São Tomé e Príncipe, onde a prevalência de excesso de peso/obesidade nas mulheres ultrapassa a marca dos $35 \%$ atrás referida. No caso dos homens as prevalências situam-se entre $24 \%$ e $32 \%$. No caso das crianças com menos de 5 anos apenas o estudo do Banco Mundial apresenta valores e são referentes a 2008, encontrando as prevalências mais altas em São Tomé e Príncipe, $12,1 \%$ e $11,1 \%$, respetivamente para meninas e meninos.

Estas diferenças podem dever-se, como já foi referido, a diferentes metodologias, nomeadamente à falta de ajustamento para variáveis de confundimento.

\section{Impacto do excesso de peso/obesidade na saúde das populações}

O excesso de peso e a obesidade são responsáveis por um aumento do risco de doença e morte, particularmente devido à sua associação a doenças cardiovasculares (hipertensão, doença coronária, doenças cardíacas e acidente vascular cerebral), diabetes tipo 2, doenças músculo-esqueléticas, como osteoartrite, apneia obstrutiva do sono e a alguns tipos de cancro ${ }^{6,8}$.

Assim, e salvaguardando a ação de outros fatores, a prevalência do excesso de peso/obesidade pode constituir um bom indicador de algumas doenças não transmissíveis, em particular as cardiovasculares e a diabetes. As doenças não transmissíveis (DNT) são um dos principais desafios para a saúde e desenvolvimento dos países, em particular os de menores recursos. São a principal causa de morte a nível mundial, tendo sido responsáveis por 38 milhões (68\%) dos 56 milhões de mortes no mundo em 2012. Mais de 40\% destas mortes ocorreram em indivíduos com idades abaixo dos 70 anos. Quase três quartos de todas as mortes por DNT, e a maioria dos óbitos prematuros, ocorrem em países de baixo e médio rendimento ${ }^{6}$.

Reconhecendo a importância do impacto das DNT no desenvolvimento dos países, a OMS desenvolveu o Plano de Ação Global das DNT, que tem como objetivo ajudar os países na prevenção e controle de DNT no período de 2013-2020. Este plano, aprovado pela Assembleia Mundial da Saúde em 2013, inclui um conjunto de nove metas e um quadro de acompanhamento global das DNT $^{6,15}$.

Estas nove metas refletem a prioridade que os países devem dar a determinadas ações de modo a reduzir os fatores de risco das DNT, entre elas está a preocupação de travar o aumento da obesidade e da diabetes $\left(7^{\mathrm{a}}\right.$ meta).

$\mathrm{O}$ acentuado aumento global da obesidade nos últimos 
death and disability, increasing the risk of cardiovascular disease, kidney failure, blindness and amputation of lower limbs ${ }^{6}$.

Since 1980, the prevalence of diabetes is increasing worldwide, rising from $4.7 \%$ to $8.5 \%$, showing for the last ten years a very rapid growth in medium and low income countries. This increase is explained largely by modifiable risk factors - reduced physical activity and unhealthy diets, poor in nutrients and highly caloric, high in fat, sugar and salt, leading to overweight conditions and obesity ${ }^{6,13,16}$.

Hypertension, diabetes, cholesterol and overweight/ obesity are responsible for $75 \%$ of cardiovascular disease in Africa. Hypertension is a very common problem among African adults with extremely high prevalence of $50 \%$ or more in some PALOP, as is Cape Verde, Mozambique and Sao Tome and Principe. The prevalence of hypertension has increased significantly in the last two or three decades, with estimates that in sub-Saharan Africa it has increased from 80 in the year 2000 to 150 million in $2015^{17}$.

The Agenda 2030 for the Sustainable Development recognizes the enormous impact of NCDs worldwide and the third of the 17 Sustainable Development Goals set out the target to, by 2030, reduce by one-third of premature mortality from NCDs through prevention and treatment ${ }^{18}$.

In the PALOP, though infectious diseases and malnutrition continue to dominate the burden of disease, the main risk factors for chronic diseases are more and more present.

Angola is the country that has the highest mortality rate due to cardiovascular disease, immediately followed by Guinea-Bissau, but these positions are reversed when the cause of death is diabetes (Table 2). Angola is also the country with the highest percentage of premature deaths due to NCDs, followed by Guinea-Bissau and Mozambique $^{19}$. trinta anos, e em particular nos países de menores rendimentos, constitui uma ameaça para a saúde das populações e para o desenvolvimento destes últimos.

A diabetes é uma doença crónica que surge quando o pâncreas não produz uma quantidade suficiente de insulina (tipo 1), ou quando o organismo não consegue utilizar a insulina produzida (tipo 2$)^{13}$. É uma doença grave, responsável pela morte prematura e incapacidade, aumentando o risco de doenças cardiovasculares, insuficiência renal, cegueira e amputação de membros inferiores ${ }^{6}$.

Desde 1980, a prevalência de diabetes tem vindo a aumentar a nível mundial, tendo passado de $4,7 \%$ para $8,5 \%$, verificando-se nos últimos dez anos um crescimento muito rápido nos países de médio e baixo rendimento. Este aumento deve-se, em grande parte, a fatores de risco modificáveis - atividade física reduzida e dietas pouco saudáveis, pobres em nutrientes e altamente energéticas, ricas em gordura, açúcares e sal, que levam ao excesso de peso e à obesidade ${ }^{6,13,16}$.

A hipertensão, a diabetes, o colesterol e o excesso de peso/obesidade são responsáveis por $75 \%$ das doenças cardiovasculares em África. A hipertensão é um problema muito comum entre os adultos africanos, com prevalências extremamente elevadas, de $50 \%$ ou mais nalguns PALOP, como é de Cabo Verde, Moçambique e São Tomé e Príncipe. A prevalência de hipertensão aumentou muito nas últimas duas ou três décadas, estimando-se que na África subsaariana aumente de 80, em 2000, para cerca de 150 milhões em $2015^{17}$.

A Agenda 2030 para o Desenvolvimento Sustentável reconhece o enorme impacto das DNT em todo o mundo e do $3^{\circ}$ dos 17 Objetivos de Desenvolvimento Sustentável consta a meta de, até 2030 , reduzir num terço a mortalidade prematura por doenças não transmissíveis via prevenção e tratamento ${ }^{18}$.

Nos PALOP, embora as doenças infecciosas e desnutrição continuem a dominar a carga da doença, os principais fatores de risco para doenças crónicas estão cada vez mais presentes.

Table 2. Age-standardized mortality rate by cause (/100 000 population). (WHO, 2014) $)^{20}$

\begin{tabular}{|c|c|c|c|c|c|c|c|c|}
\hline & \multicolumn{2}{|c|}{ Boys $(<20$ years $)$} & \multicolumn{2}{|c|}{ Men ( $\geq 20$ years) } & \multicolumn{2}{|c|}{ Girls (<20 years) } & \multicolumn{2}{|c|}{ Women ( $\geq 20$ years) } \\
\hline & $\mathrm{OvW}+\mathrm{Ob}$ & $\mathrm{Ob}$ & $\mathrm{OvW}+\mathrm{Ob}$ & $\mathrm{Ob}$ & $\mathrm{OvW}+\mathrm{Ob}$ & $\mathrm{Ob}$ & $\mathrm{OvW}+\mathrm{Ob}$ & $\mathrm{Ob}$ \\
\hline Angola & $\begin{array}{c}15.5 \\
(13.0-18.3)\end{array}$ & $\begin{array}{c}5.7 \\
(4.6-7.0)\end{array}$ & $\begin{array}{c}42.9 \\
(40.1-45.7)\end{array}$ & $\begin{array}{c}12.0 \\
(10.7-13.4)\end{array}$ & $\begin{array}{c}20.9 \\
(17.5-24.6)\end{array}$ & $\begin{array}{c}6.0 \\
(4.7-7.5) \\
\end{array}$ & $\begin{array}{c}49.1 \\
(46.1-52.0)\end{array}$ & $\begin{array}{l}18.7 \\
(16.7- \\
20.9) \\
\end{array}$ \\
\hline Cabo Verde & $\begin{array}{c}11.5 \\
(9.6-13.7)\end{array}$ & $\begin{array}{c}3.3 \\
(2.6-4.0) \\
\end{array}$ & $\begin{array}{c}31.8 \\
(29.4-34.3) \\
\end{array}$ & $\begin{array}{c}7.0 \\
(6.2-7.8) \\
\end{array}$ & $\begin{array}{c}18.3 \\
(15.0-21.7)\end{array}$ & $\begin{array}{c}5.2 \\
(4.1-6.5) \\
\end{array}$ & $\begin{array}{c}44.0 \\
(41.3-47.0)\end{array}$ & $\begin{array}{c}15.4 \\
(13.9- \\
17.1) \\
\end{array}$ \\
\hline $\begin{array}{l}\text { Guinea- } \\
\text { Bissau }\end{array}$ & $\begin{array}{c}15.8 \\
(13.3-18.5)\end{array}$ & $\begin{array}{c}8.1 \\
(6.6-9.8)\end{array}$ & $\begin{array}{c}44.0 \\
(41.1-46.9)\end{array}$ & $\begin{array}{c}16.8 \\
(15.1-18.6)\end{array}$ & $\begin{array}{c}20.4 \\
(17.2-23.8)\end{array}$ & $\begin{array}{c}8.3 \\
(6.7-10.3)\end{array}$ & $\begin{array}{c}47.8 \\
(44.8-50.8)\end{array}$ & $\begin{array}{l}24.2 \\
(21.8- \\
26.7) \\
\end{array}$ \\
\hline Mozambique & $\begin{array}{c}12.3 \\
(10.4-14.4)\end{array}$ & $\begin{array}{c}3.5 \\
(2.9-4.3) \\
\end{array}$ & $\begin{array}{c}14.1 \\
(12.7-15.6)\end{array}$ & $\begin{array}{c}3.5 \\
(3.0-3.9) \\
\end{array}$ & $\begin{array}{c}14.4 \\
(12.3-16.9)\end{array}$ & $\begin{array}{c}3.0 \\
(2.4-3.7)\end{array}$ & $\begin{array}{c}26.5 \\
(24.6-28.3)\end{array}$ & $\begin{array}{c}9.2 \\
(8.3-10.3)\end{array}$ \\
\hline $\begin{array}{l}\text { Sao Tome } \\
\text { and Principe }\end{array}$ & $\begin{array}{c}12.3 \\
(10.3-14.4)\end{array}$ & $\begin{array}{c}4.4 \\
(3.6-5.5)\end{array}$ & $\begin{array}{c}30.6 \\
(28.4-33.0)\end{array}$ & $\begin{array}{c}7.1 \\
(6.4-7.9)\end{array}$ & $\begin{array}{c}18.9 \\
(16.0-22.0)\end{array}$ & $\begin{array}{c}5.8 \\
(4.5-7.3)\end{array}$ & $\begin{array}{c}45.7 \\
(43.1-48.3)\end{array}$ & $\begin{array}{c}17.6 \\
(16.0- \\
19.2) \\
\end{array}$ \\
\hline
\end{tabular}


Tabela 2. Taxa de mortalidade por causa, ajustada para a idade (/100 000 indivíduos). (WHO, 2014)20

\begin{tabular}{|c|c|c|c|c|c|c|c|c|}
\hline & \multicolumn{2}{|c|}{$\begin{array}{c}\text { Rapazes }(<20 \\
\text { anos })\end{array}$} & \multicolumn{2}{|c|}{ Homens ( $\geq 20$ anos) } & \multicolumn{2}{|c|}{$\begin{array}{c}\text { Raparigas }(<20 \\
\text { anos) }\end{array}$} & \multicolumn{2}{|c|}{ Mulheres ( $\geq 20$ anos) } \\
\hline & $\mathrm{ExP}+\mathrm{Ob}$ & $\mathrm{Ob}$ & $\mathrm{ExP}+\mathrm{Ob}$ & $\mathrm{Ob}$ & $\mathrm{ExP}+\mathrm{Ob}$ & $\mathrm{Ob}$ & $\mathrm{ExP}+\mathrm{Ob}$ & $\mathrm{Ob}$ \\
\hline Angola & $\begin{array}{c}15,5 \\
(13,0-18,3)\end{array}$ & $\begin{array}{c}5,7 \\
(4,6-7,0) \\
\end{array}$ & $\begin{array}{c}42,9 \\
(40,1-45,7)\end{array}$ & $\begin{array}{c}12,0 \\
(10,7-13,4)\end{array}$ & $\begin{array}{c}20,9 \\
(17,5-24,6)\end{array}$ & $\begin{array}{c}6,0 \\
(4,7-7,5)\end{array}$ & $\begin{array}{c}49,1 \\
(46,1-52.0)\end{array}$ & $\begin{array}{l}18.7 \\
(16,7- \\
20,9)\end{array}$ \\
\hline Cabo Verde & $\begin{array}{c}11,5 \\
(9,6-13,7)\end{array}$ & $\begin{array}{c}3,3 \\
(2,6-4,0)\end{array}$ & $\begin{array}{c}31,8 \\
(29,4-34,3)\end{array}$ & $\begin{array}{c}7,0 \\
(6,2-7,8)\end{array}$ & $\begin{array}{c}18,3 \\
(15,0-21,7)\end{array}$ & $\begin{array}{c}5,2 \\
(4,1-6,5)\end{array}$ & $\begin{array}{c}44,0 \\
(41,3-47,0)\end{array}$ & $\begin{array}{l}15,4 \\
(13,9- \\
17,1) \\
\end{array}$ \\
\hline $\begin{array}{l}\text { Guiné- } \\
\text { Bissau }\end{array}$ & $\begin{array}{c}15,8 \\
(13,3-18,5)\end{array}$ & $\begin{array}{c}8,1 \\
(6,6-9,8)\end{array}$ & $\begin{array}{c}44,0 \\
(41,1-46,9)\end{array}$ & $\begin{array}{c}16,8 \\
(15,1-18,6)\end{array}$ & $\begin{array}{c}20,4 \\
(17,2-23,8)\end{array}$ & $\begin{array}{c}8,3 \\
(6,7-10,3)\end{array}$ & $\begin{array}{c}47,8 \\
(44,8-50,8)\end{array}$ & $\begin{array}{l}24,2 \\
(21,8- \\
26,7) \\
\end{array}$ \\
\hline Moçambique & $\begin{array}{c}12,3 \\
(10,4-14,4) \\
\end{array}$ & $\begin{array}{c}3,5 \\
(2,9-4,3) \\
\end{array}$ & $\begin{array}{c}14,1 \\
(12,7-15,6) \\
\end{array}$ & $\begin{array}{c}3,5 \\
(3,0-3,9) \\
\end{array}$ & $\begin{array}{c}14,4 \\
(12,3-16,9) \\
\end{array}$ & $\begin{array}{c}3,0 \\
(2,4-3,7) \\
\end{array}$ & $\begin{array}{c}26,5 \\
(24,6-28,3) \\
\end{array}$ & $\begin{array}{c}9,2 \\
(8,3-10,3) \\
\end{array}$ \\
\hline $\begin{array}{l}\text { São Tomé e } \\
\text { Príncipe }\end{array}$ & $\begin{array}{c}12,3 \\
(10,3-14,4)\end{array}$ & $\begin{array}{c}4,4 \\
(3,6-5,5)\end{array}$ & $\begin{array}{c}30,6 \\
(28,4-33,0)\end{array}$ & $\begin{array}{c}7,1 \\
(6,4-7,9)\end{array}$ & $\begin{array}{c}18,9 \\
(16,0-22,0)\end{array}$ & $\begin{array}{c}5,8 \\
(4,5-7,3)\end{array}$ & $\begin{array}{c}45,7 \\
(43,1-48,3)\end{array}$ & $\begin{array}{l}17,6 \\
(16,0- \\
19,2) \\
\end{array}$ \\
\hline
\end{tabular}

When we account the years of life lost due to NCDs, it is Cape Verde who leads with 55\%, followed by Guinea-Bissau with $18 \%{ }^{20}$.

Table 3 shows the prevalence of diabetes and overweight and obesity as a risk factor. Cape Verde and Angola are the countries with the highest values. Values are very similar between men and women for diabetes, but in relation to overweight and obesity, the differences are striking, with women showing the highest values ${ }^{21}$.
Angola é o país que apresenta a taxa de mortalidade mais elevada devida a doenças cardiovasculares, logo seguida da Guiné-Bissau, posições que se invertem quando a causa de morte é a diabetes (tabela 2). Angola é também o país com maior percentagem de mortes prematuras devido a DNT, a que se segue a Guiné-Bissau e Moçambique ${ }^{19}$.

Quando contabilizamos os anos de vida perdidos devido a DNT é Cabo Verde quem lidera com $55 \%$, seguido da Guiné-Bissau com $18 \%{ }^{20}$.

Na tabela 3 apresentam-se os valores da prevalência da diabetes e do excesso de peso e obesidade como fatores de risco. Cabo Verde e Angola são os países com maiores prevalências. Em relação à diabetes os valores são muito semelhantes entre homens e mulheres, mas em relação ao excesso de peso e à obesidade as diferenças são notórias, tendo as mulheres os valores mais eleva$\operatorname{dos}^{21}$.

Table 3. Prevalence of diabetes and related risk factors (Overweight and Obesity) (\%)

\begin{tabular}{|c|c|c|c|c|c|c|c|c|c|}
\hline \multirow{2}{*}{ PALOP } & \multicolumn{3}{|c|}{ Diabetes } & \multicolumn{3}{|c|}{ Overweight } & \multicolumn{3}{|c|}{ Obesity } \\
\hline & Men & Women & Total & Men & Women & Total & Men & Women & Total \\
\hline Angola & 5.8 & 5.5 & 5.6 & 21.1 & 33.1 & 27.1 & 5.1 & 11.9 & 8.5 \\
\hline Cabo Verde & 6.7 & 6.9 & 6.8 & 29.1 & 38.9 & 34 & 7.7 & 15.7 & 11.7 \\
\hline $\begin{array}{l}\text { Guinea- } \\
\text { Bissau }\end{array}$ & 5.3 & 5.1 & 5.2 & 17.7 & 29.3 & 23.5 & 3.2 & 9.4 & 6.3 \\
\hline Mozambique & 4.5 & 4.7 & 4.6 & 11.9 & 26.6 & 19.4 & 1.6 & 7.4 & 4.5 \\
\hline $\begin{array}{l}\text { Sao Tome } \\
\text { and Principe }\end{array}$ & & & & & & & & & \\
\hline
\end{tabular}


Tabela 3. Prevalência da diabetes e dos fatores de risco relacionados (Excesso de Peso e Obesidade) (\%)

\begin{tabular}{|c|c|c|c|c|c|c|c|c|c|}
\hline \multirow{2}{*}{ PALOP } & \multicolumn{3}{|c|}{ Diabetes } & \multicolumn{3}{|c|}{ Excesso de Peso } & \multicolumn{3}{|c|}{ Obesidade } \\
\hline & Homens & Mulheres & Total & Homens & Mulheres & Total & Homens & Mulheres & Total \\
\hline Angola & 5.8 & 5.5 & 5.6 & 21.1 & 33.1 & 27.1 & 5.1 & 11.9 & 8.5 \\
\hline Cabo Verde & 6.7 & 6.9 & 6.8 & 29.1 & 38.9 & 34 & 7.7 & 15.7 & 11.7 \\
\hline $\begin{array}{l}\text { Guiné- } \\
\text { Bissau }\end{array}$ & 5.3 & 5.1 & 5.2 & 17.7 & 29.3 & 23.5 & 3.2 & 9.4 & 6.3 \\
\hline Moçambique & 4.5 & 4.7 & 4.6 & 11.9 & 26.6 & 19.4 & 1.6 & 7.4 & 4.5 \\
\hline $\begin{array}{l}\text { São Tomé e } \\
\text { Príncipe }\end{array}$ & & & & & & & & & \\
\hline
\end{tabular}

\section{Conclusion}

The burden of disease in low-income countries is changing rapidly from infectious diseases to non-communicable diseases, verifying a displacement of the risks of infectious diseases in children, to the risks of non-communicable diseases in adults. These changes, known as the epidemiological transition, are related to the ageing population, with the decrease in infant mortality, the causes of death and the change in the risk factors to which populations are exposed. But in much of sub-Saharan Africa, the main risks which remain are those associated with poverty and those affecting children. In these countries the growth of NCDs was not accompanied by decrease of infectious diseases, and instead of being a phase transition, there is an accumulative process $^{22,23}$.

The high estimates of the prevalence of overweight/ obesity pointed to the PALOP, especially for GuineaBissau and Angola, should receive full attention of health authorities of these countries because of its association with NCDs.

A survey of the situation of overweight conditions in childhood and adolescence is also urgent, because overweight and obesity in childhood increase the risk of obesity, NCDs, premature death and disability in adulthood $^{24}$.

Among the young African population there has been a replacement of traditional diets for unhealthy diets rich in fats, sugar, and salt, responsible for some NCDs. The WHO estimates that $70 \%$ of premature deaths in adulthood result from behaviours that begin in adolescence ${ }^{10}$. In 2012, the World Health Assembly approved a comprehensive plan for maternal and child nutrition, which specified six global nutrition targets for 2025. The target 4 aims at preventing the increase in the rate of child-

\section{Conclusão}

A carga de doença em países de menores rendimentos está a mudar rapidamente das doenças transmissíveis para as não transmissíveis, verificando-se um deslocamento dos riscos de doenças transmissíveis em crianças, para os riscos de doenças não transmissíveis em adultos. Estas mudanças, conhecidas como a transição epidemiológica, estão relacionadas com o envelhecimento da população, com a diminuição da mortalidade infantil, com as causas de morte e com a mudança nos fatores de risco a que as populações se encontram expostas. Mas, em grande parte da África subsaariana, os principais riscos continuam a ser aqueles associados à pobreza e os que afetam as crianças. Nestes países o crescimento das DNT não foi acompanhado pelo decréscimo das doenças infecciosas, assim, em vez de se assistir a uma fase de transição, verifica-se um processo de acumulação $0^{22,23}$.

As elevadas estimativas da prevalência de excesso de peso/obesidade apontadas para os PALOP, em especial para a Guiné-Bissau e Angola, devem merecer a maior atenção das autoridades de saúde destes países devido à sua associação com as DNT.

Também um levantamento da situação sobre o excesso de peso na infância e na adolescência é urgente, pois o excesso de peso e a obesidade na infância aumentam o risco de obesidade, de DNT, de morte prematura e deficiência na vida adulta ${ }^{24}$.

Entre os jovens africanos tem-se verificado uma substituição das dietas tradicionais por dietas menos saudáveis, ricas em gorduras, açúcar e sal, responsáveis por algumas DNT. A OMS estima que $70 \%$ das mortes prematuras na idade adulta resultam de comportamentos que se iniciam na adolescência ${ }^{10}$.

Em 2012, a Assembleia Mundial da Saúde aprovou um 
hood overweight state above the reference value of 2012 (7\%). The objective of this plan is to draw attention to a set of interventions and economic policies that can help the Member States and its partners to prevent the increase of an overweight condition in children ${ }^{24}$. Non-communicable diseases are currently one of the main challenges for the health and development of countries, both in terms of human suffering and the economic damage they cause in countries, particularly in those populations with lower incomes. No government can ignore the growing burden of $\mathrm{NCDs}^{6}$.

The scarcity of data on the impact of cardiovascular disease in sub-Saharan Africa is due to the lack of research, caused by low-skilled human resources and by reduced available funding resources ${ }^{25}$.

PALOP, as other countries in sub-Saharan Africa, have huge difficulties in implementing programs aiming to combat the risk factors of NCDs, not only due to lack of resources, but also by a lack of data and information of their own populations, which often ignore the symptoms and severity of disease.

The Global Status Report on Noncommunicable Diseases shows that mortality and morbidity are heavily concentrated in countries with lower income, which leads to a loss of productivity due to premature deaths, and the high personal and national cost of treatments acting as barriers to poverty reduction and sustainable development ${ }^{6}$.

The incidence and prevalence of NCDs in the PALOP are not yet fully identified, and a better knowledge of the situation in relation to overweight/obesity is needed. Research is urgently needed to assess the effectiveness of interventions to prevent and control obesity.

Actions to prevent and control overweight in childhood should be implemented together with other actions to resolve other nutritional problems such as low birth weight, stunting, wasting, breastfeeding, anemia in women and low birth weight ${ }^{24}$.

\section{Conflict of interests}

The authors declare that there are no financial and/or personal relationships that could be viewed as presenting a potential conflict of interests. plano abrangente para a nutrição materno-infantil e da criança, que especificava seis metas globais de nutrição para 2025. A quarta meta tem como propósito não aumentar o excesso de peso na infância, tendo como referência o valor de 2012 (7\%). O objetivo deste plano é chamar a atenção para um conjunto de intervenções e políticas económicas que podem ajudar os Estados-Membros e seus parceiros a prevenir o aumento do excesso de peso em crianças ${ }^{24}$.

As doenças não transmissíveis (DNT) são atualmente um dos principais desafios para a saúde e desenvolvimento dos países, tanto em termos do sofrimento humano que causam, como pelo prejuízo que provocam na economia dos países, em particular nos países de menores rendimentos. Nenhum governo pode ignorar o crescente fardo das $\mathrm{DNT}^{6}$.

A escassez de dados sobre o impacto das doenças cardiovasculares na África Subsaariana deve-se à falta de investigação, causada pela baixa especialização dos recursos humanos e por recursos disponíveis reduzidos ${ }^{25}$. Os PALOP, tal como noutros países da África Subsaariana, têm enormes dificuldades em implementar programas que visem combater os fatores de risco das DNT, não apenas por falta de meios, mas também por falta de dados e de informação da própria população, que muitas vezes desconhece os sintomas e a gravidade das doenças.

O relatório mundial sobre as DNT revela que a mortalidade e a morbilidade estão fortemente concentradas nos países de menores rendimentos, o que leva a uma perda de produtividade devido às mortes prematuras e a elevados custos pessoais e nacionais com os tratamentos, agindo como barreiras para a redução da pobreza e para um desenvolvimento sustentável ${ }^{6}$.

A incidência e a prevalência das DNT nos PALOP não estão ainda completamente identificadas, mesmo em relação ao excesso de peso/obesidade há necessidade de conhecer melhor a situação.

A investigação é urgentemente necessária para avaliar a eficácia das intervenções para prevenir e controlar a obesidade. As ações para prevenir e controlar o excesso de peso na infância devem ser implementadas a par com outras ações com vista à resolução de outros problemas nutricionais, como o baixo peso, o atraso de crescimento, o aleitamento materno, a anemia em mulheres e o baixo peso ao nascimento ${ }^{24}$.

\section{Conflito de interesses}

Os autores declaram não existir qualquer relação pessoal ou financeira que possa ser entendida como representando um potencial conflito de interesses. 


\section{References/ Referências}

1. Flegal KM, Carroll MD, Ogden CL, Curtin LR. Prevalence and trends in obesity among US adults, 1999-2008. JAMA 2010; 303: 235-41.

2. Rokholm B, Baker JL, Sorensen TIA. The levelling off of the obesity epidemic since the year 1999-a review of evidence and perspectives. Obes Rev 2010; 11: 835-46.

3. Stamatakis E, Wardle J, Cole TJ. Childhood obesity and overweight prevalence trends in England: evidence for growing socioeconomic disparities. Int $\mathrm{J}$ Obes 2010; 34: 41-47.

4. Ng M, Fleming T, Robinson M, et al. Global, regional, and national prevalence of overweight and obesity in children and adults during 1980-2013: a systematic analysis for the Global Burden of Disease Study 2013. Lancet 2014, 384: 766-81.

5. IFPRI - International Food Policy Research Institute. 2015. Global Nutrition Report 2015: Actions and Accountability to Advance Nutrition and Sustainable Development. Washington, DC.

6. WHO. Global Status Report on Noncommunicable Diseases 2014. Geneva. 2014. In URL: http://apps.who.int/iris/bitstre am/10665/148114/1/9789241564854 eng. pdf

7. Abubakari AR, Lauder W, Agyemang C, Jones M, Kirk A and Bhopal RS. Prevalence and time trends in obesity among adult West African populations: a meta-analysis. Obesity Reviews 2008; 9: 297-311.

8. WHO. What are the health consequences of being overweight? 2013. In URL: http:// www.who.int/features/qa/49/en/

9. Ellulu M, Abed Y, Rahmat A, Ranneh Y, Ali F. Epidemiology of obesity in developing countries: challenges and prevention. Global Epidemic Obesity 2014. In URL: http:// dx.doi.org/10.7243/2052-5966-2-2.
10. PRB. Addressing Risk Factors for Noncommunicable Diseases Among Young People in Africa: Key To Prevention and Sustainable Development. 2015. In URL: http://www. prb.org/pdf15/ncds-africa-datasheet.pdf

11. USAID/SPRING. Nutrition-Related Noncommunicable Disease Regional Profile: Africa. In URL: https://www.spring-nutrition. org/sites/default/files/publications/briefs/ spring_ncd_africa_summary_profile_1.pdf

12. WHO. Obesity and overweight. Fact sheet N³11. 2015. In URL: http://www.who.int/ mediacentre/factsheets/fs $311 / \mathrm{en} /$

13. WHO. Global Report on Diabetes. Executive Summary. 2016. In URL. http://apps.who. int/iris/bitstream/10665/204874/1/WHO_ NMH NVI 16.3 eng.pdf?ua $=1$

14. World Bank, 2016. Health Nutrition and Population Statistics. In URL: http://data.worldbank.org/data-catalog/health-nutrition-andpopulation-statistics

15. WHO. Global action plan for the prevention and control of noncommunicable diseases 2013-2020. 2013. In URL: $\quad$ http://apps.who.int/iris/bitstre am/10665/94384/1/9789241506236 eng.pdf

16. WHO. Global strategy on diet, physical activity and health. 2004. In URL: http:// www.who.int/dietphysicalactivity/strategy/ eb11344/strategy_english_web.pdf

17. WHO. The health of the people: what works - the African Regional Health Report 2014. World Health Organization. Regional Office for Africa. 2014. In URL: http://extranet.who.int/iris/restricted/bitst ream/10665/137377/4/9789290232612. pdf?ua $=1$

18. WHO. Noncommunicable diseases progress monitor, 2015. 2015. In URL: $\quad$ http://apps.who.int/iris/bitstre am/10665/184688/1/9789241509459_eng. pdf
19. WHO Atlas of Health Statistics of the African Region 2014 - Health situation analysis of the African Region. World Health Organization. Regional Office for Africa, 2014. 2014. In URL: http://www.aho.afro.who.int/ sites/default/files/publications/921/AFROStatistical_Factsheet.pdf?ua $=1$

20. WHO. African Health Observatory (AHO) Regional and Country Profiles. Factsheets of Health Statistics, 2014. 2014. In URL: http://www.aho.afro.who.int/profiles information/?lang=en

21. WHO. Diabetes country profiles, 2016. 2016. In URL: http://www.who.int/diabetes/country-profiles/en/

22. Lim SS, Vos T, Flaxman AD, Danaei G, Shibuya K, Adair-Rohani $\mathrm{H}$ et al. A comparative risk assessment of burden of disease and injury attributable to 67 risk factors and risk factor clusters in 21 regions, 19902010: a systematic analysis for the Global Burden of Disease Study 2010. Lancet 2012; 380:2224-60

23. Prista A. Sedentarismo, urbanização e transição epidemiológica. Revista Científica da Universidade Eduardo Mondlane, Série: Ciências Biomédicas e Saúde Pública 2012; 1: $28-38$.

24. WHO. Global nutrition targets 2025. 2014. In URL: http://www.who.int/nutrition/globaltarget-2025/en/

25. Mocumbi AO. Lack of focus on cardiovascular disease in sub-Saharan Africa. Cardiovasc Diagn Ther 2012; 2:74-77. 